\title{
Gutenberg és a MOOC
}

\author{
BERDE ÉVA \\ Budapesti Corvinus Egyetem \\ Beérkezett: 2020. november 13., elfogadva: 2021. június 11.
}

Tanulmányunkban a Tömeges Nyitott Online Kurzusok (angolul: Massive Open Online Education, rövidítése MOOC) kialakulásával és óriási méretủ növekedésével foglalkozunk. A rövid előzményekkel rendelkező, mai formájában 2011-ben startolt új típusú oktatási forma jelenleg már alapképzéses és mesterképzéses diplomát is ad. Ily módon beszélhetünk MOOC egyetemekről, melyek sok szerző szerint a Christensenféle romboló újítás megtestesítői a felsőoktatásban. A MOOC népszerüsége egyúttal jelzi, hogy a napjainkban lezajló generációváltás egyben oktástechnikai változással is párosul. Cikkünkben összehasonlítjuk a MOOC egyetemek jóléti hatásait a Gutenbergféle könyvnyomtatás jóléti hatásaival. A szolgáltatói oldalhoz kapcsolódóan pedig bemutatjuk a MOOC-platformok jelenleg működő finanszírozási modelljeit.

Kulcsszavak: Tömeges Nyitott Online Kurzusok (MOOC), jóléti többlet, kampuszos egyetemek, MOOC egyetemek, MOOC-finanszírozás

The study analyses the emergence and huge growth of the Massive Open Online Education. This new type of education which started in 2011 in its current form and so has only a very short history, now offers both bachelor's and master's degree. MOOC universities are seen by many authors as the embodiment of Christensen's destructive innovation. At the same time, the popularity of MOOC indicates that the generational change taking place today is accompanied by a change in educational technology. The present paper compares the welfare effects of MOOC universities with the welfare effects of Gutenberg's book printing. In connection with the service provider side, the paper presents the financing models of the MOOC platforms as well.

Keywordsः Massive Open Online Courses, welfare surplus, brick and mortar universities, MOOC universities, financing the MOOC

Levelező szerző: Berde Éva, Budapesti Corvinus Egyetem, 1093 Budapest, Fővám tér 8.

E-mail: eva.berde@uni-corvinus.hu 


\section{Bevezetés}

A z eBay 1995-ös alapítása (Haryani-Hidayanto-Budi 2018) óta a gazdaság számos más területén születtek sikeres platformok, melyek egy-egy korábban megszokott szolgáltatást a korábbiaktól eltérő eszközökkel valósítanak meg (szállodai vendéglátás, éttermi asztalfoglalás, hívásos taxi szolgáltatás, csoportokon belüli kapcsolattartás stb.). Az új eszközök használatát minden esetben a gyors kereskedelmi interneten keresztüli kommunikáció tette lehetővé. Az oktatásba, ezen belül a felsőoktatásba is megérkezett az új forma, melyet a Tömeges Nyitott Online Kurzusok (angolul: Massive Open Online Education, a továbbiakban MOOC) testesítenek meg.

$\mathrm{A} z$ új oktatástechnikai formák népszerüvé válása egybeesik az $\mathrm{Y}$, de különösen a $\mathrm{Z}$ generáció ${ }^{1}$ korábbi generációkhoz képest lényegesen megváltozott életszemléletének elterjedésével (Geck 2007; Montana-Petit 2008). Már az Y generáció is teljes könnyedséggel használta az internetet és épített az internetes alkalmazások lehetőségeire, de a $Z$ generáció gyakorlatilag ebbe a környezetbe született bele. A Z generáció tagjai képesek egyszerre több mindennel is foglalkozni, ugyanakkor az egy témában való hosszabb idejü elmélyedés számukra nehézséget jelent. Az internetes MOOC-platformokon keresztüli tanulás, a saját ütemezés szerinti elörehaladással, az órák visszapörgetésének lehetőségével és a gépi értékeléssel számukra „a normál tanulási forma”, az a környezet, ahol egyértelmüen otthon érzik magukat, és ami vonzó is számukra. Ezért is fontos, hogy az oktatáspolitikusok kellő hangsúlyt fektessenek a MOOC-platformokra, és használják ki a platformok nyújtotta képzési lehetőségeket.

A MOOC története rendkívül rövid, kezdete egybeesik a legidősebb $Z$ generációbeli fiatalok kiskamasz korával. A MOOC első formájának a szakirodalom a kanadai Manitoba Egyetem 2008-as, ún. cMOOC online kurzusát tartja (LiyanagunawardenaAdams-Williams 2013), melynek témája a konnektivizmus és a konnektív tudás volt. Pontosan a konnektivizmus elvén alapul a cMOOC, ahol a tanulók és a tanárok egymással szoros kapcsolatban vannak, és mintegy együtt tanulnak. A „c” az angol kifejezés első betűjéből származik. A kurzuson a 25 fizetős és kreditért tanuló hallgató mellett 2200 ingyenes, de kreditet nem szerző hallgató vett részt a világ minden részéről. A cMOOC definíciójának megfelelően a kurzushoz online platform kapcsolódott, mely összekapcsolta a résztvevőket, és egyben lehetőséget biztosított a felmerült problémák közösségi megtárgyalására és az együttes tanulásra, amikor is az előadók és a tanulók azonos jogokat élveztek.

Online kurzusokat az egyes egyetemek 2008 után - sőt már elötte - is folyamatosan tartottak, de ezek nem váltak nagyobb méretűvé egészen 2011-ig. 2011 októberében hirdette meg három ingyenes online kurzusát a Stanford Egyetem: adatbázisok, gépi tanulás és mesterséges intelligencia témakörben (Tong-Li 2018). Ezek mindegyikére több mint 100 ezer hallgató jelentkezett a Föld minden pontjáról. A híres professzorok által tartott videókurzusokat gépi értékelésü feladatok egészítették ki, megalapozva ezzel az ún. xMOOC professzori előadásokra épülő oktatási formáját ( $\mathrm{Ng}-$ Widom 2014). $\mathrm{Az}$ elnevezés $\mathrm{x}$ betűje az angol extended szóból származik, mely az osztálytermekben el-

Az Y és Z generációk születési idejét egyes szerzők kis eltéréssel értelmezik, a leggyakrabban az 19811996 közt születetteket $Y$, a fiatalabbakat Z generációnak nevezik. 
hangzott előadások kiterjesztését jelöli. Az előadások nem interaktívak, a tanár leadja a tananyagot, a tanuló pedig önállóan megtanulja. A kurzus végén a hallgatók a menet közben megoldott feladataik eredménye és a végső, szintén gépi értékelésű vizsga alapján teljesítést igazoló bizonyítványt kaphattak. A bizonyítványt szerzők száma azonban már ezeken a kurzusokon is $20 \%$ alatti volt. A kezdeti óriási lelkesedés hatalmas lökést adott a további MOOC-kurzusok indításához, és 2012-től kezdve ezek a MOOCkurzusok óriási fejlődésnek indultak. 2017-től pedig már alapképzéses és mesterképzéses diplomát is lehet szerezni az online tanfolyamokon, illetve ún. mikroigazolásokat (angolul: micro credentials), melyeket egy meghatározott menetrend szerint összegyüjtve vagy kampuszokon történő hagyományos képzésekhez kapcsolva végül alapképzéses és mesterképzéses diplomát is kaphat a résztvevő. Ezek a diplomakurzusok fizetősek, szemben a kezdeti ingyenes MOOC-tanfolyamokkal, bár a tandij szinte soha nem éri el a kampuszos képzések 10\%-át se. Közülük jó néhányon részt lehet venni megfigyelői státuszban (angolul: audit participation), más szempontból is korlátozott jogokkal (rövidebb idő, esetleg kizárás a feladatmegoldási lehetőségből stb.). A diplomát nem adó MOOC-kurzusok is egyre inkább törekednek fizetős elemek bevonására, bár ezek között még mindig jóval több az ingyenes lehetőség.

A MOOC-kurzusok indítását mind alkotóik részéről, mind a potenciális diákok oldaláról nagy érdeklődés övezte, és népszerűségük ma sem csökken. A kezdeti hozzáállást üzleti és etikai szempontból is jól jellemezte az ún. kék óceán elmélet (angolul: blue ocean theory), ami azonban mára meglehetősen elkopott. Üzleti szempontból a Kék Óceán, ami egyben elfogadott marketing terminológia (Kim 2005), azt sugallja egy új piaci résztvevőnek, hogy ne a már telített piacokkal foglalkozzon, hanem találjon a fogyasztásba eddig nem bevont területeket, ahol azután új vevőket vonzhat magához. Etikai szempontból pedig a kék óceán az eddig érintetlen, azaz a felsőoktatást elérni nem tudó rétegekre vonatkozik, akiknek a tudásbővítése nagyban hozzájárulhat az emberiség fejlődéséhez (Reich-Ruipérez-Valiente 2019). Cikkünkből egyértelmüen ki fog derülni, hogy a kék óceán elmélet üzleti szempontból másképp, etikai szempontból pedig végül is alig-alig teljesült. Ezzel együtt a MOOC ma már egyértelmủen részét, sőt nagyon is fejlődő részét képezi a felsőoktatásnak. Christensen és munkatársai a christenseni elméletnek megfelelően egyenesen romboló felsőoktatási újításról írnak. Úgy vélik, hogy a hagyományos egyetemi modell napjainkra elavult, és a korábbi felsőoktatási modell összeomlása ma már megfordíthatatlan (Christensen et al. 2011). Semmiképp nem biztosítható a régi modell pénzügyi fenntarthatósága, egyetlen kérdés az, hogy a MOOC újító modelljét kik fogják bevezetni. Maguk a hagyományos felsőoktatási intézmények vagy külső agresszív szereplők. A végeredmény ugyanaz lesz, teljesen megváltozik a felsőoktatás színtere.

Akár egyetértünk, akár nem Christensennek és munkatársainak a véleményével, a MOOC-oktatás rohamos növekedése tagadhatatlan (Christensen et al. 2011). Cikkünkben először ezt a fejlődést mutatjuk be, majd megkíséreljük megbecsülni a MOOC jóléti hatásait, összevetve a Gutenberg-féle könyvnyomatás jóléti hatásaival. Ezek után a MOOC-platformok finanszírozásával foglalkozunk, majd összefoglaljuk következtetéseinket. 


\section{A MOOC rohamos fejlődése}

Mint ahogy a bevezetőben írtuk, a tényleges MOOC-oktatás kezdetét 2011-re, a Stanford Egyetem három óriási népszerűségnek örvendő online kurzusának meghirdetésére datálhatjuk. Ettől az időponttól kezdve mind a kurzusokat fogadó platformok, mind az ilyen jellegű képzéseket biztosító egyetemek száma rohamos növekedésnek indult, nem is beszélve a hallgatói létszámokról. Az óriási méreteket jól mutatja a kurzusok számát és a résztvevők létszámát illusztráló két grafikon

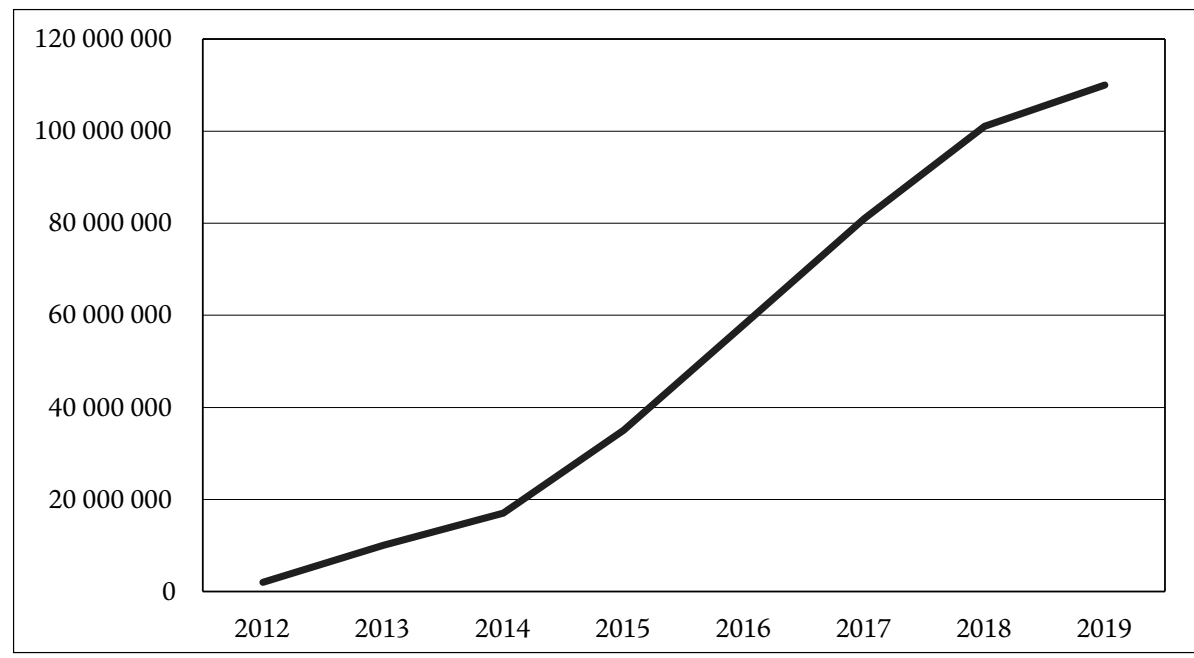

1. ábra: A MOOC hallgatói létszámának alakulása. Forrás: Shab (2019a, 2019b, 2019c, 2020) adatai és grafikonpontjai

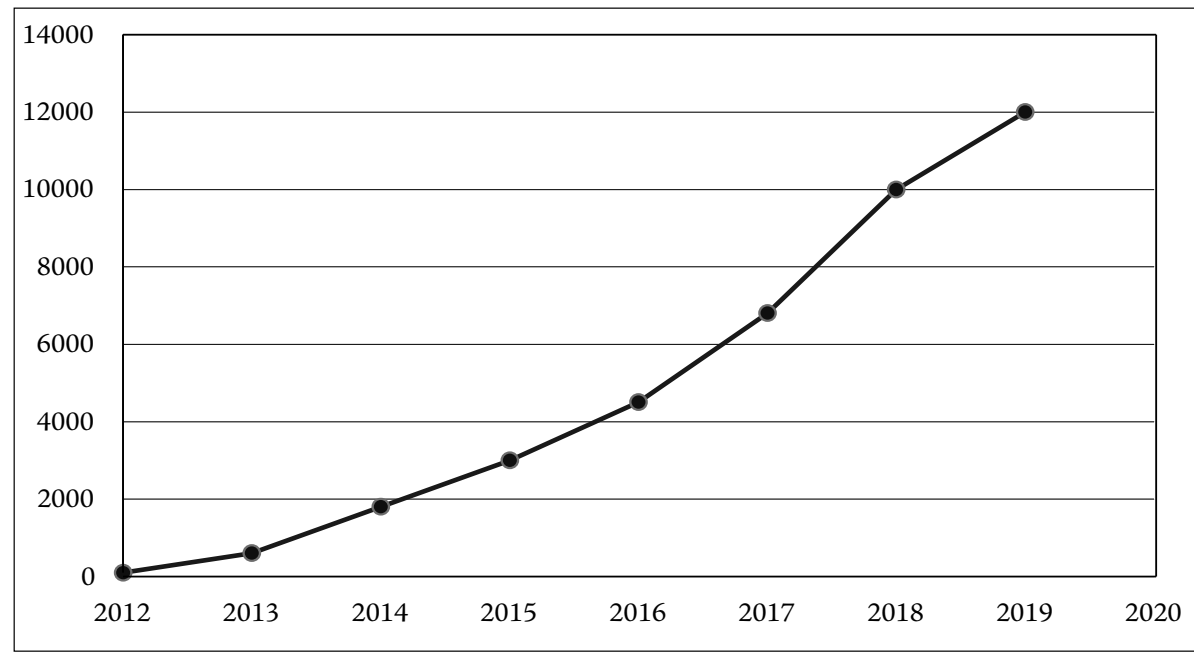

2. ábra: A meghirdetett MOOC-kurzusok száma. Forrás: Shab (2019b) grafikonja alapján 
$\mathrm{Az}$ 1. és 2. ábrán bemutatott adatokhoz kapcsolódóan néhány fontos megjegyzést kell tennünk. Először is tudnunk kell, hogy a MOOC-kurzusokról nem létezik hivatalos statisztikai adatgyüjtés. A részvételi számokat össze lehet esetleg gyűjteni az egyes platformok honlapjáról, de olyan sok platform létezik, és a kisebbek néhány ezres hallgatói közönsége is összességében nagy értéket ad. Így erről az oldalról szinte lehetetlen megközelíteni a statisztikákat. Az 1. és 2. ábra adatait a Class Central gyüjtő honlap Dhawal Shah által írt különböző tényközlö, illetve blog jellegű bejegyzései alapján gyüjtöttük össze, esetenként grafikonpontokról olvasva le a kérdéses értékeket. A bejegyzések jellegénél fogva a kategóriák tartalma nem mindig egyértelmü. A kurzusokat illetően például egy hosszabb részidőszakra vonatkozóan szintén Dhawal Shah tollából lényegesen alacsonyabb értékű idősor is található (Shah 2019b). A bejegyzések többszöri elemzése után arra a következtetésre jutottunk, hogy a 2. ábra kurzusai az összes meghirdetett kurzusra vonatkoznak, és amennyiben egy évben kétszer, háromszor is meghirdették ugyanazt a kurzust, akkor az kettő vagy három értékkel szerepel a statisztikában. A kisebb számokat tartalmazó, sajnos csak egy részidőszakra vonatkozó adattábla pedig egynek tekint egy kurzust, akár egyszer, akár sokszor hirdették meg az év során. Az 1. ábrát tekintve pedig Dhawal Shah gondolatmenetét követve úgy kell tekintenünk a létszámot, hogy ha valaki egy évben kétszer is beiratkozott egy akármilyen MOOC-kurzusra, akkor két hallgatónak számít az összlétszámot tekintve. A felsőoktatás témakörét vizsgálva arról sem szabad megfeledkeznünk, hogy a MOOCkurzusok egy nem túl nagy, de azért jelentős része nem felsőfokú, hanem középszintű ismeretek átadását célozza meg.

Az esetleges értelmezési gondok ellenére az 1. és 2. ábra egyértelmüen tanúsítja, hogy a MOOC-kurzusok 2011 óta óriási fejlődésen mentek keresztül. Ez a fejlődés megmutatta, hogy a méret ugyancsak számít. A nagy platformok, illetve rajtuk keresztül azok a nagy egyetemek, melyek csatlakoztak az új típusú képzéshez, minden bizonynyal élvezik a méretgazdaságosság előnyeit. A kisebb egyetemeknek ugyanakkor ez a helyzet hátrányt jelent a diákokért folytatott versenyben (Christensen et al. 2011). A Christensenék által romboló újításnak nevezett folyamatot Baker és Passmore (2016) is hasonlóképpen írja le. A romboló újítás jellemzésére még az eredetileg több mint 70 évvel korábban írt, majd újra megjelentetett, Schumpeter (1976) által megfogalmazott ipari mutációra is hivatkoznak, ami elkerülhetetlenül modernizálja a termelési struktúrát.

A MOOC terjedésével a felsőoktatás valóban nemzetközivé vált, még akkor is, ha nem feltétlen sikerült a leghátrányosabb helyzetü potenciális hallgatókat bekapcsolni a képzésbe. Sokaknak, akik nem a leghátrányosabb körülmények közt élnek, de amúgy anyagi, élethelyzeti vagy bármilyen más okból mégse engedhetnék meg maguknak a felsőoktatásban való részvételt, a MOOC óriási segítséget jelent, mert így ők is bekapcsolódhatnak az egyetemi képzésbe. A MOOC különösen jó lehetőséget biztosít a pályájukat módosítani kívánó vagy magukat továbbfejleszteni akaró felnőttek részére.

A MOOC-platformok közül a kezdeti útkeresés után egyre jobban kiválasztódnak azok - egyértelmúen a legnagyobbak -, amelyek alapképzéses és mesterképzéses diplomát is kínálnak. Ez a folyamat 2017-ben kezdődött, és 2018-ban, a MOOC-diplomát adó kurzusainak megugrásával a MOOC második nagy csúcspontját jelentették. Az 1. táblázat a MOOC-diplomát adó kurzusainak számát mutatja a jelenlegi négy legnagyobb platform kezelésében. A felsorolásból kimaradtak a kínai platformok, melyek szintén óriási méretűek, de Shah (2019a) szerint statisztikai adataikat más metodológia 
szerint gyüjtötték, és nem hasonlíthatóak össze a világ többi MOOC-platformjának adataival.

1. táblázat: A MOOC-alapú diplomát nyújtó kurzusok száma 2017 és 2019 közt, valamint a mikrokreditet nyújtó MOOC-kurzusok 2019-ben

\begin{tabular}{lcccc}
\hline & 2017 & 2018 & 2019 & 2019 mikrokredit kurzusok \\
\hline Coursera & 4 & 11 & 16 & 420 \\
edX & 1 & 9 & 10 & 292 \\
FutureLearn & 4 & 18 & 23 & 49 \\
Udacity & 1 & 1 & 1 & 40 \\
\hline Összesen & 10 & 39 & 50 & 801 \\
\hline
\end{tabular}

Forrás: Shab (2019a)

A diplomát nyújtó kurzusok mellett egyre népszerübbek az ún. mikrokreditet (angolul: micro credentials) biztosító, vagyis az egyetemi képzésben figyelembe vehető részkurzusok. Ezeket a legtöbbször egy kampuszbeli kurzus kötelező részeként írják elő, de nem csak a kampuszos hallgatók jelentkezhetnek rájuk. A mikrokreditekhez hasonlóan a mikromesterkurzusok is egyre népszerübbek, melyek a mesterképzést bontják részekre, és ha egy hallgató minden ilyen részegységből sikeresen levizsgázott, akkor diplomát is kap.

Mind ez idáig úgy tűnhet, hogy a MOOC a felsőoktatás sikertörténete, legalábbis azon diákok részére, akik számára valóban elérhető. Eddig ugyanis alig-alig említettük az árnyoldalait. Pedig negatívumokat is bőven fel lehet sorolni. Az ingyenes részuétel, illetve ingyenes audit részvétel a diákok számára meglehetősen vonzó, ugyanakkor csak a valóban eltökéltek jutnak el a sikeres vizsga letételéig. A rendkívül alacsony, Reich és Ruipérez-Valiente (2019) szerint 10\% alatti sikeres vizsgaarány két lényeges okkal is magyarázható. Egyrészt sok esetben az ingyenesség a jelentkezők részéről kevéssé átgondolt döntéseket eredményez, és sokan már az első előadások anyagát se töltik le. Másrészt a külső instrukciókat csak videón biztosító tanulási forma nagy önállóságot és kitartást igényel, és sokan a legjobb szándék ellenére sem képesek lépést tartani. Ezért a ma szinte kizárólag jellemző $\mathrm{xMOOC} \mathrm{esetében} \mathrm{is} \mathrm{igyekeznek} \mathrm{külön} \mathrm{web} \mathrm{fórumokat}$ biztosítani a kurzus hallgatói részére, ahol megbeszélhetik egymással a főbb kérdéseket, és esetenként - általában külön díj befizetése mellett - egy tanári csapat is válaszol a hallgatók kérdéseire. A webes hallgatói közösség építése alapvetően a cMOOC-ot jellemzi, de épp az igényekhez igazodva a két típusú MOOC-képzés közti éles határok megszünőben vannak.

Még akkor is, ha a MOOC-kurzusok hallgatói képesek követni az utasításokat, és sikeresen le is vizsgáznak, a képzés során kénytelenek nélkülözni a hagyományos „tégla és malter” egyetemeknek egy rendkívül vonzó tulajdonságát: nem tudnak olyan kapcsolati hálót kiépíteni, ami aztán későbbi életútjuk során sok segítséget biztosítana a számukra. Ezt is pótolni igyekeznek azok a webes fórumok, ahol a MOOC egyetemekhez kapcsolódva egymással kommunikálhatnak a diákok, illetve a MOOCképzéseket előszeretettel ajánlják a felnőttek továbbképzésére és pályamódosítási ter- 
veik megvalósítására, amikor a kapcsolati háló jelentősége, a korábban összegyüjtött tapasztalatok eredményeként, már nem olyan nagy jelentőségü.

Összefoglalva ennek a résznek a tanulságait: könnyen lehet, hogy a MOOC egyetemek a romboló újítás részei, bár bizonyos elemeiben véleményünk szerint semmiképp nem tudják pótolni a kampuszbeli képzéseket. Ezért a jövőben sokkal inkább valószínüsíthető a két felsőoktatási forma egymás melletti, illetve egymással kooperáló müködési mechanizmusa, mint akár a kampuszos felsőoktatás, akár a MOOC egyeduralma. Mindenképpen érdemes azonban a folyamat részeseivé válni, mert amelyik egyetem lemarad, az a MOOC-platformok méretgazdaságossága miatt lehet, hogy a jövőben ki is marad a folyamatból. A MOOC bővítette a tanulni vágyók előtt álló lehetőségeket, ezért jóléti hatása semmiképp nem hanyagolható el. A következő részben pontosan ezzel a kérdéssel, a jóléti hatások becslésével foglalkozunk.

\section{A MOOC jóléti hatásai}

A MOOC felbukkanása bizonyos szempontból hasonlít a Gutenberg-féle könyvnyomtatás általánossá válásához. Igaz, a két újítás közt több mint 570 év telt el, viszont mind a Gutenberg-féle könyv, mind a MOOC a tudásterjesztés egy új formáját valósította meg. A mozgatható betűkkel való nyomtatás 1439-ben történt feltalálása (pontosabban újrafeltalálása, mivel az antik Kínában jóval korábban használt módszerek feledésbe merültek) rendkívül felgyorsította először Európán belül, majd a többi elérhető földrészen is az információ áramlását (Chappell-Bringhurst 1970), és ezzel a felsőoktatás fejlődését is. A MOOC-ot tekintve, ez a forma pedig tovább bővítette a 2000-es évek elején egyébként már meglehetősen magas felsőoktatási létszámot, és teljesen nemzetközivé tette az oktatást. A könyvekből történő tanulás is jó módszere az új ismeretek elsajátításának, de az instrukciókat tartalmazó és feladatokkal összekapcsolt videós elöadások a könyveknél jóval hatékonyabban képesek új információkat átadni az arra fogékonyak részére.

Azt, hogy mennyit jelentett az emberiségnek, pontosabban a korabeli angol lakosoknak a könyvnyomtatás, Dittmar (2011) a jóléti hatások becslésével igyekezett megmutat$\mathrm{ni}^{2}{ }^{2} \mathrm{E} z$ a hatásbecslés teljességgel a neoklasszikus mikroökönómia eszközeivel dolgozik, vagyis mellőz minden normatív szemléletet. Nem kívülröl, meghatározott elvek alapján dönti el a jóléti változást, hanem az árváltozás és a vásárolt mennyiség változásának eredményeként. A jólétet a nettó fogyasztói többlethez kapcsolja. ${ }^{3}$ Nem tesz semmi olyanfajta kijelentést, miszerint a társadalom számára az a jó, ha minél többen és minél több könyvet olvasnak, nem különbözteti meg a „jó könyveket” a „rossz könyvektől”, nem írja elö, hogy kinek kellene olvasnia stb. Egyszerűen az átlagos fogyasztó könyvvásárlási mennyiségéből és a piaci árakból von le következtetéseket.

\footnotetext{
A jóléti hatások becslésének Dittmar (2011) által is használt módszere alapvetően egy viszonylag régi eredmény, a Hicksi hasznosság függvény (Hicks 1939) segítségével végrehajtott teljes árhatásfelbontáson alapul. A jóléti becslések ilyen módszere mégis csak a 2000-es évek elején vált népszerűvé, amikor is több témában azonos technikával becsült jóléti becslést is publikáltak, melyeknek valószínüleg nem teljes listáját az alábbi felsorolás tartalmazza: a kisteherautókra (Petrin 2002), az internetre (Goolsbee-Klenow 2006), az édességek gyarmati beszállítás okozta sokszínüségére (Hersh-Votb 2009), a személyi számítógépekre (Greenwood-Kopecky 2013), az automatizálásra vonatkozóan pedig (Eden-Gaggl 2015).

3 A nettó fogyasztói többlet annak a legmagasabb árnak, amit a fogyasztó még hajlandó megadni a termék vagy szolgáltatás egy egységéért, és a piaci ár különbségének aggregált összege.
} 
A módszer leírása részletesen megtalálható Dittmar (2011) könyvében. Dittmar relatív kockázatkerülö ${ }^{4}$ hasznossági függvényt feltételezve a nyomtatott könyvek árváltozásának eredményeként a fogyasztói döntést vizsgálja. A teljes árhatás felbontásakor két módon is közelíti a nettó fogyasztói többletet. Egyrészt megvizsgálja, hogy a régi hasznossági szint új árak melletti elérésekor mennyi jövedelmet, azaz szubvenciót kellene adni a fogyasztónak ahhoz, hogy az új hasznossági szintre jusson. Ez a jóléti különbség ún. kompenzációs becslése. Amikor pedig az új hasznossági szinten vizsgáljuk, hogy a régi árak mellett mekkora jövedelmet áldozna fel a fogyasztó, ha visszakerülne a régi hasznossági szintre, akkor a jóléti becslés egyenértékű verzióját valósítjuk meg.

Mindkét számítási módszer a Hicks-féle hasznossági függvény paramétereinek becslésén alapszik, melyet az ismert mennyiségi, ár és fogyasztói költséghányad adatok függvényében regressziós becsléssel határoznak meg. A módszer meglehetősen adatigényes. Dittmar hangya szorgosságával gyüjtötte össze a szükséges adatokat a korabeli Angliára vonatkozóan. Rendkívüli alapossággal dolgozva két időszakra is megbecsülte a nyomtatott könyvek jóléti hatásait: 1540 és 1590 közt, valamint 1630 és 1690 közt. Természetes, hogy a MOOC egyetemek jóléti hatásainak becslésekor ilyen alapos számítások nem végezhetőek el. Nemcsak a MOOC felsőoktatási térnyerésének nagyon rövid időszaka (gyakorlatilag három évről van szó) miatt, hanem a korábban jelzett adatgyüjtési problémák következtében is. Ráadásul a MOOC egyetem nem tekinthető lényegileg külön jószágnak a hagyományos egyetemekhez képest, és így egy egyetemi „összetett kosárral” kell dolgoznunk, melynek árát a MOOC egyetemek bővülő súlya folyamatosan csökkenti.

Szerencsére a Hicks-féle hasznossági függvénnyel végzett számítások jól közelíthetők két alternatív módszerrel is (az alternatív módszerek leírását lásd pl. Diewert [2008], Dittmar [2011]), valamint Greenwood és Kopecky [2013] tanulmányaiban). Mi az alternatív módszerek közül a Törnqvist (1936) alapján számszerüsített árindex segítségével kidolgozott eljárást alkalmaztuk, és csak egyenértékű verziót számítottunk.

A jóléti többlet egyenértékü verziójának Törnqvist módszeréből kiinduló verziója az alábbi képlettel dolgozik:

$$
\lambda_{E V}=\left[\left(\frac{p_{t}}{p_{0}}\right)^{\left(s_{t}+s_{0}\right) / 2}\right]^{-1}-1,
$$

ahol $p_{0}$ és $p_{t}$ az árak az induló (0) periódusban, és a záró $(t)$ periódusban, éspedig a felsőoktatás részesedése a fogyasztó költségvetésében (vagyis azt mutatja, hogy jövedelméből mennyit költ felsőoktatásra), pontosabban a részesedések logaritmikus hányadosa. A továbbiakban az (1) képlettel kiszámított eredményt jóléti többletnek nevezzük.

$\mathrm{Az}$ (1) képlet számszerüsítéséhez az alap- és mesterképzés (továbbiakban egyetem) árára és a fogyasztók egyetemre költött kiadási részarányára lenne szükségünk. Nem volt lehetőség minden adat pontos megfigyelésére, ezért szimulációs számításokat végeztünk. Tudnunk kell, hogy az (1) képlet segítségével (akárcsak a hicksi hasznossági

\footnotetext{
4 A paragrafusban szereplő mikroökonómiai fogalmak jelentése: a kockázatkerülő fogyasztó szívesebben fogad el egy kisebb várható értékủ pénzösszeget, ha a nagyobb várható érték mellett a vesztesége is nagy lehet. A hasznossági függvény a fogyasztó értékítéletét számszerűsíti. A teljes árhatás azt mutatja, hogy amennyiben az ár változik, akkor a fogyasztott mennyiség hogyan változik. A teljes árhatást szokás összetevőkre bontani, mely egyrészt a relatív árváltozás hatását méri, másrészt a reáljövedelem változásának hatását.
} 
függvényen alapuló eredeti jólét számítás során) egyetlen ország átlagos fogyasztójára (azaz egy átlagos hallgatóra) vonatkozóan tudjuk meghatározni a jóléti többletet. Ez a MOOC-ot is magában foglaló egyetemek esetében annyiban torzít, hogy egy adott országban nyújtott szolgáltatás jóléti hatásait egyetlen országban vizsgáljuk, pedig a szolgáltatást a Föld jó néhány országából igénybe veszik.

A kampuszos egyetemi képzések árára vonatkozóan a Massachusetts Institute of Technology (továbbiakban MIT) 2020-as árait figyeltük meg az interneten közzétett adatainak segítségével, a MOOC egyetemekre vonatkozóan pedig ugyanígy tettünk az edX egyetemi kurzusaira vonatkozóan. Megállapítottuk, hogy alsó becslésként az MIT kurzusok 10-szer annyiba kerülnek, mint az edX egyetemek tandíja. A 2016-os - még MOOC egyetemek nélküli - árakat egységnyinek tekintettük, majd a bevezetésre kerülő MOOC egyetemek tandíját 0,1-nek vettük. Szimulációs számításunk azt jelentette, hogy az egyetemi „kosárban” a MOOC egyetemek súlyát változtattuk, először 0,1-nek, majd 0,2-nek véve. Az egyetemi kiadások jövedelmen belüli hányadát 12-12\%-nak tekintettük a 0. és a t. időszakban is (a diákhitelt is figyelembe véve Johnstone [2004] alapján becsülve), majd a számításokat megismételtük ennél lényegesen nagyobb, 30\%-os jövedelemaránnyal. A különböző jövedelmi arányok mellett a MOOC egyetemek becsült jóléti hatását a 2. táblázat mutatja

2. táblázat: A MOOC egyetemek szimulációs számításokon alapuló jóléti hatása az USA-ban

\begin{tabular}{|c|c|c|c|c|c|}
\hline & \multicolumn{3}{|c|}{$\begin{array}{l}\text { Az egyetemi kiadások a jöve- } \\
\text { delem } 12 \% \text {-át teszik ki }\end{array}$} & \multicolumn{2}{|c|}{$\begin{array}{l}\text { Az egyetemi kiadások a jöve- } \\
\text { delem } 30 \% \text {-át teszik ki }\end{array}$} \\
\hline $\begin{array}{l}\text { temek részese- } \\
\text { dése az egyetemi } \\
\text { "kosárban" }\end{array}$ & $10 \%$ & $20 \%$ & & $10 \%$ & $20 \%$ \\
\hline $\begin{array}{l}\text { Egyenértékü ver- } \\
\text { zióval becsült jóléti } \\
\text { hatás }\end{array}$ & 0,052206 & 0,113026 & $\begin{array}{l}\text { Egyenértékű } \\
\text { verzióval becsült } \\
\text { jóléti hatás }\end{array}$ & 0,072137 & 0,157854 \\
\hline
\end{tabular}

A 2. táblázat alapvetően szimulációs számításokra támaszkodik, így eredményeit se értékelhetjük úgy, mintha minden eleme valós statisztikai adatokon alapulna. Azt azonban jelzi, hogy a MOOC egyetemek még akkor is $5 \%$-os jólétnövelö hatással bírnak, ha az egyetemi kiadások a jövedelem $12 \%$-át teszik ki, és az egyetemi „fogyasztói kosárban” a kampuszos egyetemek 90\%-kal, a MOOC egyetemek 10\%-kal részesülnek. Ha ezeket a szimulációs eredményeket a 3. táblázat segítségével összehasonlítjuk a Dittmar (2011) által leírt jóléti változásokkal, akkor láthatjuk, hogy ezek a hatások viszonylag jelentősnek tekinthetők.

3. táblázat: A Gutenberg-féle nyomatott könyvek jóléti hatása Angliában (Dittmar 2011) számítások alapján. A számításokat Dittmar a becsült Hicks-féle hasznossági függvénnyel végezte, a táblázat az egyenértékü verziót tartalmazza

Nyomatott könyvek 1540-1590 Nyomtatott könyvek 1630-1690

Egyenértékü jóléti hatás $\quad 0,145 \quad 0,123$


A nyomtatott könyvek jóléti hatását Dittmar minimum 0,123-ra (12,3\%-ra) becsli a korabeli Angliában. Ehhez képest valóban jelentősnek tűnik a mi legkisebb szimulációs eredményünk, a 0,052 (5,2\%) is. Az, hogy a MOOC jóléti hatása a jövőben ténylegesen hogyan alakul, még számtalan tényezőtől függ. A jóléti hatások értelmezésénél azt is fontos figyelembe vennünk, hogy az elvégzett számítások csak a nettó fogyasztói többletre vonatkoznak. Egy termék vagy egy szolgáltatás biztosítását azonban nem a nettó fogyasztói többlet, hanem a termelők és szolgáltatók profitérdekeltsége teszi lehetővé. Ez pedig nemcsak a termék árától, és a belőlük megvásárolt mennyiségtől, hanem a költségek finanszírozásától is függ. A következő részben a MOOC-platformok finanszírozási lehetőségeit mutatjuk be.

\section{A MOOC finanszírozása}

Mint minden felsőoktatási intézmény, így a MOOC-ok esetében is kulcskérdés a finanszírozás. A hagyományos felsőoktatás szinte mindenütt anyagi gondokkal küszködik (Christensen et al. 2011). Az anyagi gondok miatt gyakran ott is, ahol korábban államilag finanszírozták a képzést, bevezették a hallgatók önfinanszírozási kötelezettségét, illetve ahol korábban is tandíjat kellett fizetni, ott elkezdték a befizetendő összeg fokozatos emelését. A hagyományos egyetemek egymással versengenek a hallgatókért, és a különböző felsőfokú képzések is gyakran elszipkázzák előlük a hallgatókat. Az állami finanszírozású egyetemek az állami költségvetés szűkülése, a profit érdekeltségü egyetemek pedig az oktatási költségek folyamatos emelkedése miatt egyre nehezebb helyzetbe kerülnek.

A közoktatást, és valamely mértékben a felsőoktatást is, a közgazdasági szakirodalom közjószágnak vagy kvázi közjószágnak tekinti (Marginson 2011). Több könyvtárnyi irodalom született annak magyarázatára, hogy a felsőoktatásban szerzett tudás a társadalom teljes jólétét növeli, és nem csak azoknak biztosít előnyt, akik a tudást megszerezték. Ezzel a filozófiával igazolják a felsőoktatás közpénzekből történő finanszírozásának szükségességét, melyet a szinte minden piacgazdaságot sújtó költségvetési gondok következtében egyre kisebb mértékben tudnak megvalósítani. A MOOCplatformok esetében a közpénzekből történő finanszírozás kérdése bonyolultabb módon jelentkezik. Maga a platform és a platform segítségével biztosított oktatási szolgáltatás ugyanis meghatározott érdekeltségek tulajdonában van, melyek országonkénti hovatartozása egyértelmúen követhetö. A hallgatóság, vagyis a fogyasztók azonban a világ minden pontjáról kerülnek ki, így nagyon nehéz eldönteni, hogy melyik ország közpénzéből kellene finanszírozni az adott MOOC-ot. Kialakult egy fogalom, a globális közjószág fogalma (Kanowski-Yao-Wyatt 2019; Stiglitz 1999), mely a felsőoktatás vonatkozásában alapesetben azt jelenti, hogy a valahol kiképzett szakember több munkáltató és több ország számára is jóléti előnyöket nyújt. A diplomával rendelkezők tevékenysége emellett nemcsak munkáltatója jólétét szolgálja, hanem hozzájárul az egész társadalom müveltségi szintjének emeléséhez, és nem utolsósorban annak az országnak a GDP-növeléséhez, ahol a munkavállaló dolgozik. A MOOC sokkal általánosabbá tette a globális közjószág fogalmát, mert egy adott ország által szervezett képzésen a legkülönbözőbb országokban élök vesznek tömegesen részt. Amennyiben a hallgatók végzés után saját országukban - mely különbözik a MOOC szolgáltató országától kezdenek el dolgozni, akkor az egyik ország révén megszerzett muníciót egy másik or- 
szágban „értékesítik”, és a jóléti transzfer közvetlenül a képzés után elkezdődik. Az Európai Unión belül az Unió közös akcióterveinek és közös tevékenységének, illetve bizonyos európai országok erős jóléti jellegének megfelelően egy-egy program erejéig megvalósultak közpénzből finanszírozott MOOC-kezdeményezések (Schuwer et al. 2015), de az utóbbi időben nem olvastunk ilyen típusú közös MOOC-finanszírozásokról. A két leghíresebb európai platform, az angol gyökerekkel rendelkező FutureLearn és a német érdekeltségü Iversity pontosan ugyanolyan finanszírozási eszközöket alkalmaz, mint a világ legnagyobb (többnyire amerikai érdekeltségü) platformjai.

A MOOC-platformok igyekeznek kihasználni a méretgazdaságosságból származó előnyöket. Ennek ellenére ezeknek a platformoknak a monetarizálása is sokszor problémás, az eddig kialakult modellek közül még nem választódott ki a minden körülmények közt alkalmazható legjobb változat. Általában a kurzustól és a lehetőségektől függően különböző finanszírozási modelleket alkalmaznak. Ezek a modellek hasonlítanak a más elektronikus platformok esetében használt monetarizálási eljárásokhoz, hisz az eBay indulása óta létrejövő új típusú szolgáltatások mindegyike két- vagy többoldalú platform. Ilyenkor megszokott pénzszerzési technika lehet, hogy hirdetők biztosítják a platform müködését, vagy esetleg a platformokhoz kapcsolódó fogyasztók valamely rétege számára ingyenes vagy lényegesen olcsóbb a szolgáltatás, mert a többi fogyasztói rétegtől befolyó összegek fedezik a költségeket. Az is lehetséges, hogy megengedik, sőt egyenesen ajánlják, hogy a platformot dijfizetés mellett másik szolgáltató is használja, és így saját fogyasztóik részére ingyenessé tudják tenni a hozzáférést. Gyakran előforduló módszer az is, hogy a platform alapszolgáltatását ingyen lehet igénybe venni, de ha valaki minőségibb vagy pluszszolgáltatást is igényel, azért már fizetni kell. A legtöbb platformnál, a MOOC-hoz hasonlóan egyszerre több finanszírozási technikát is alkalmaznak.

A továbbiakban nézzük meg konkrétan, hogy a MOOC-platformok esetében milyen finanszírozási módok, azaz monetarizálási technikák müködnek. Ismertetésünk Baker és Passmore (2016), valamint Belleflamme és Jacqmin (2016) tanulmányán alapul, természetesen saját nézőpontunknak megfelelően tálalva.

\section{a) Oklevél modell}

Ez a modell gyakorlatilag fordítottja a hagyományos „tégla és malter” egyetemek finanszírozásának, ahol a diákok tandíjat fizetnek, de a bizonyítványt a tanulmányi időszak végén megfelelő teljesítmény esetén ingyen kapják. Az oklevél modellben müködő MOOC-ban a diákok ingyen csatlakozhatnak a kurzushoz, amennyiben viszont bizonyítványt szeretnének kapni, akkor ezért fizetniük kell. A bizonyítvány jelzi a munkáltatók felé kitartásukat, és leírja megszerzett képességeiket. A MOOC-kurzusok esetében, különösen egy-két évvel a 2011-es indulás után még nem tettek szert az egyes kurzusok olyan hírnévre, sem a kurzusok és bizonyítványok akkreditációjára, hogy a bizonyítvány igazán értékes lett volna. A MOOC alapképzéses és mesterképzéses diplomái azonban már akkreditáltak, és értékük is lényegesen megnövekedett.

A z oklevél modell az alacsony végzési arányszámok miatt magában rejti azt a veszélyt, hogy csökkentik a bizonyítvány megszerzéséhez szükséges tudásszintet, ezzel ösztönözve a hallgatókat arra, hogy próbálják megszerezni a bizonyítványt, és így fizessenek is érte. Az egyetemi MOOC-képzések bevezetése azonban csökkenti ezt a veszélyt, és 
különösen a kampuszos képzésekkel együtt kínált MOOC-kurzusok kénytelenek megkövetelni a megfelelő színvonalat.

\section{b) Freemium modell}

Ennek a finanszírozási formának az elnevezése az angol nyelvű free (ingyenes) és a premium (jutalék) szavak összeolvasztásából született meg. Olyan lehetőségeket takar, melyekben bizonyos szolgáltatások ingyenesek, másokért viszont fizetni kell. Ez például jelentheti azt, hogy a kurzusokon való megfigyelő részvétel (angolul: audit participation) ingyenes, de az ingyenesség általában csak a teljes kurzus időtartamánál rövidebb időre vonatkozik. Az oklevél modellel közös elem, hogy a bizonyítványért a freemium modellben is fizetni kell. De ezenkívül még számos más fizetős szolgáltatást kínál fel a platform: a tanárokkal való közvetlen konzultáció lehetőségét, hallgatói fórumokon való részvételt, külön korrepetálást, a kurzus részvételi idejének meghosszabbítását stb. Bár sok internetalapú szolgáltatás esetében (pl. vírusirtók pénzes és ingyenes változata, streamelő szolgáltatások rövid idejű igénybevétele, majd pedig előfizetése stb.) ez a freemium jellegü módszer működik, nehézséget jelent az egyes platformok tudásanyagának viszonylag kis differenciáltsága. Csak akkor tud egy platfrom pénzt kérni egy plusz szolgáltatásért, ha a másik hasonló kurzust kínáló platform is ezt teszi. Amennyiben a másik platform ingyenesen nyújtja a plusz szolgáltatást, akkor a diákok inkább a másik platform kurzusára iratkoznak be.

A Freemium modell ugyanakkor megengedi a halasztott fizetést is oly módon, hogy a kezdetben csak megfigyelői részvételre jelentkező hallgatók a későbbiekben még meghosszabbíthatják a tanulásra rendelkezésükre álló időt, vagy kérhetnek plusz szolgáltatást, ha úgy látják, hogy ez megéri nekik.

\section{c) Hirdetési modell}

Ez az elektronikus platformok egyik leggyakrabban alkalmazott finanszírozási eszköze. A platform tulajdonosa díj fizetésének ellenértékeként megengedi, hogy egy harmadik fél hirdetéseket helyezzen el a platformján. A MOOC esetében a tanfolyamoktól függően a hallgatók érdeklődésének megfelelő hirdetéseket játszanak be. A hallgatóknak ily módon nem, vagy legfeljebb csökkentett összegü részvételi díjat kell fizetniük, viszont el kell szenvedniük a rájuk erőltetett reklámokat. Ugyanúgy, mint más platformok, általában a MOOC-ok se tesznek szert elegendő bevételre a hirdetésekből, így általában csak kiegészítő finanszírozási eszköznek használják.

\section{d) Munkabelypárositási modell}

A hirdetési modellhez hasonlóan ez a finanszírozási forma azt használja ki, hogy a kurzusok hallgatói egy meghatározott érdeklődési körű rétegből kerülnek ki, és az általuk választott tudásportfólió elsajátításán dolgoznak. Jövendő munkáltatóik érdekeltek abban, hogy a hallgatók teljesítményéről részletesebb információkat kapjanak, és a számukra legmegfelelőbbnek tűnő diákoknak munkalehetőséget kínáljanak. A platform dij fizetése ellenében meg is engedi a munkáltatóknak a hallgatók részeredményeibe és végső értékelésébe való betekintést, ami a hallgatóknak több szempontból is előnyös: 
kevesebb tandíjat kell fizetniük, és ha elég ügyesek, akkor rögtön a kurzus végén munkaajánlatot kapnak.

\section{e) Alvállalkozói modell}

Ebben a modellben a platform lehetővé teszi más egyetemek számára, hogy elhelyezzék nála a MOOC-kurzusukat. Ezen a módon pl. a hagyományos egyetemek is tarthatnak MOOC-kurzusokat anélkül, hogy lenne saját platformjuk. Az alvállalkozó modell legfontosabb eleme tehát, hogy biztosítja a MOOC-kurzusok elindításának lehetőségét, és azzal már nem törődik, hogy az alvállalkozó egyetem, vagy akár más vállalkozások, amelyek saját dolgozóikat kívánják tovább képezni, milyen módon finanszírozzák a saját képzéseiket. A Coursera tipikus példája az ilyen finanszírozási módszernek, mely indulásától kezdve biztosította az infrastruktúrát, de soha nem tartozott egyetlen egyetemhez se, mindig csak szerződést kötött egyetemekkel.

\section{f) Kampuszos képzést imitáló modell}

Baker és Passmore (2016), valamint Belleflamme és Jacqmin (2016) írásakor még nem müködött ez a finanszírozási forma, az elnevezés tőlünk származik. Azokra az alapképzéses és mesterképzéses kurzusokra utal, ahova a hallgatók ugyanúgy tandíjért iratkozhatnak be, mint a kampuszbeli képzésekre. Ezek a formák egyre népszerübbek, beleértve azokat a kevert kurzusokat is, melyek egy része a kampuszokon, más része a MOOC keretében zajlik. Mesterképzéshez kapcsolódóan pedig a mikromesterkurzusok részekre bontják le a teljes képzést, és a hallgatóknak külön-külön kell beiratkozniuk az egyes mikrokurzusokra, melyekért bizonyítványt csak díj ellenében kapnak. Az így szerzett bizonyítványok összegyüjtése során saját ütemük szerint eljuthatnak odáig, hogy végül a mesterképzéses diplomát is megkapják.

Bár a kampuszos képzést imitáló modellekbe bizonyos konstrukciókban fizetés és diplomaszerzés lehetősége nélkül ingyen is be lehet kapcsolódni, ezek a kurzusok mégis alapvetően a diplomákra vágyókat célozzák meg. Ezek a kurzusok jelzik, hogy a jövőben a MOOC egyetemek növekedése várható, és a „tégla és malter” egyetemeknek valóban meg kell tanulniuk az együttélést a MOOC egyetemekkel, illetve érdemes a hagyományos egyetemeknek meggondolniuk, hogy bekapcsolódjanak az új típusú képzésekbe is.

\section{Következtetések}

A MOOC az internetes lehetőségekre épülő, rendkívül gyorsan fejlődő, leginkább a felsőoktatásban és felnőttképzésekben használható oktatási forma. Bár a világ elmaradottabb régióiba - a kezdeti optimista elképzelések ellenére - a MOOC-nak se sikerült „betörnie”, de a további fejlődés során miniden bizonnyal területileg is várható az előrelépés.

A MOOC-ra vonatkozó adatok összegyüjtése és kategorizálása annak ellenére óriási nehézségekbe ütközik, hogy a képzés az interneten keresztül zajlik, és az egyes MOOCplatformok minden fontos információt tudhatnak saját hallgatóikról. Az adatok összegyưjtése elsősorban az egységes statisztikai rendszer és adatszolgáltatási kötelezettség hiánya miatt bizonyul rendkívül nehéznek. 
A MOOC jóléti hatása akár még a Gutenberg-féle könyvnyomtatás jóléti hatásaival is felveheti a versenyt, de a jóléti hatás mérete az adatok iránti rendkívüli érzékenység miatt nem megbízható. Egy biztos, a MOOC jóval olcsóbban szolgáltatja az alap- és mesterképzéses diplomát, mint a „tégla és malter” egyetemek. Ugyanakkor a MOOC-nak elsősorban az első diploma megszerzésekor mindenképpen vannak hátrányai is, mert elektronikus fórumok megteremtése mellett se tudja azt a közösségi hálót biztosítani, amit a hagyományos képzések nyújtanak azáltal, hogy megkövetelik a hallgatók fizikai részvételét.

A MOOC egyértelmüen beleillik a Christensen-féle romboló újítás elméletébe, azok a hagyományos felsőoktatási intézmények, amelyek nem hajlandók erről tudomást venni, vagy dacolnak a magát is tovább gerjesztő fejlődési folyamattal, mindenképpen versenyhátrányba fognak kerülni. Érdemes tehát elgondolkodni azon, hogy a magyar felsőoktatás színterén hogyan kell egymáshoz viszonyulnia a MOOC-nak és a hagyományos kampuszos oktatásnak.

\section{Epilógus}

A cikk benyújtásakor még nem realizálódott az az óriási fejlődés, melyen a járvány időszakában ment keresztül a MOOC. A pandémia alatt a hallgatói létszám a Class Central adatai szerint másfélszeresére nőtt, és a legnagyobb Platform, a Coursera 2021. április 1-jétől tőzsdei vállalattá vált. Mindezzel párhuzamosan az ingyenesen látogatható MOOC-kurzusok száma folyamatosan csökken, az alap- és mesterképzéses diplomát nyújtó kurzusok közt pedig egyáltalán nem található ilyen. Igaz, a tandíjak általában szignifikánsan alacsonyabbak, mint a hagyományos amerikai egyetemek tandíjai.

\section{IRODALOM}

Baker, R. M. \& Passmore, D. L. (2016) Value and Pricing of MOOCs. Education Sciences, Vol. 6. No. 2. https://doi.org/10.3390/educsci6020014

Belleflamme, P. L. \& Jacqmin, L. (2016) An Economic Appraisal of MOOC Platforms: Business Models and Impacts on Higher Education. CESifo Economic Studies, Vol. 62. No. 1. pp. 148-169.

Chappell, W. \& Bringhurst, R. (1970) A Short History of the Printed Word. Boston, David R Godine Pub.

Christensen, C. M., Horn, M. B., Caldera, L. \& Soares, L. (2011) Disrupting College: How Disruptive Innovation Can Deliver Quality and Affordability to Postsecondary Education. Lexington, Innosight Institute.

Diewert, E. W. (2008) Consumer Surplus and the Measurement of Ex Post Welfare Change. Lecture Notes, University of British Columbia. 581.

Dittmar, J. (2011) The Welfare Impact of a New Good: The Printed Book. Department of Economics, American University.

Eden, M. \& Gaggl, P. (2015) On the Welfare Implications of Automation. The World Bank. Geck, C. (2007) The Generation Z Connection: Teaching Information Literacy to the Newest Net Generation. Toward a 21st-century school library media program 235. 
Goolsbee, A. \& Klenow, P. J. (2006) Valuing Consumer Products by the Time Spent Using Them: An Application to the Internet. American Economic Review, Vol. 96. No. 2. pp. 108-113.

Greenwood, J. \& Kopecky, K. A. (2013) Measuring the Welfare Gain from Personal Computers. Economic Inquiry, Vol. 51. No. 1. pp. 336-347.

Haryani, C. A., Hidayanto, A. N. \& Budi, N. F. A. (2018) Sentiment Analysis of Online Auction Service Quality on Twitter Data: A Case of E-Bay. In: 2018 6th International Conference on Cyber and IT Service Management (CITSM). IEEE, pp. 1-5.

Hersh, J. \& Votr, H.-J. (2009) Sweet Diversity: Colonial Goods and the Rise of European Living Standards After 1492. No. 7386. Discussion Paper No. 7386. July 2009. London, Centre for Economic Policy Research.

Hicks, J. R. (1939) Value and Capital. Clarendon Press, Oxford.

Johnstone, D. B. (2004) Cost-Sharing and Equity in Higher Education: Implications of Income Contingent Loans. In: Markets in Higer Education. Dordrecht, Springer, pp. 37-59.

Kanowski, P., Yao, D. \& Wyatt, S. (2019) SDG 4: Quality Education and Forests - The Golden Thread. In: P. Katila (ed.) Sustainable Development Goals: Their Impacts on Forests and People. Cambridge University Press. pp. 108-145.

KIм, W. Сн. (2005) Blue Ocean Strategy: From Theory to Practice. California Management Review, Vol. 47. No. 3. pp. 105-121.

Liyanagunawardena, T. R., Adams A. A. \& Williams S. A. (2013) MOOCs: A Systematic Study of the Published Literature 2008-2012. International Review of Research in Open and Distributed Learning, Vol. 14. No. 3. pp. 202-227.

Marginson, S. (2011) Higher Education and Public Good. Higher Education Quarterly, Vol. 65. No. 4. pp. 411-433.

Montana, P. J. \& Petit, F. (2008) Motivating and Managing Generation X and Y on the Job While Preparing for Z: A Market Oriented Approach. Journal of Business E Economics Research (JBER), Vol. 6. No. 8. pp. 35-40.

Ng, A. \& Widom, J. (2014) Origins of the Modern MOOC (Xmooc). In: F. M. Hollands $\&$ D. Tirthali (eds) MOOCs: Expectations and Reality: Full Report. Teachers College, Columbia University. pp. 34-47.

Petrin, A. (2002) Quantifying the Benefits of New Products: The Case of the Minivan. Journal of Political Economy, Vol. 110. No. 4. pp. 705-729.

Reich, J. \& Ruipérez-Valiente, J. A. (2019) The MOOC Pivot. Science, Vol. 363. No. 6423. pp. 130-131.

Schumpeter, J. A. (1976) Capitalism, Socialism and Democracy (1942) J. Econ. Literature, Vol. 20. p. 1463.

Schuwer, R., Gil-Jaurena, I., Aydin, C. H., Costello, E., Dalsgaard, Ch., Brown, M., Jansen, D. \& Teixeira, A. (2015) Opportunities and Threats of the MOOC Movement for Higher Education: The European Perspective. International Review of Research in Open and Distributed Learning, Vol. 16. No. 6. pp. 20-38.

Sнaн, D. (2019a) By the Numbers: MOOCs in 2019. https://www.classcentral.com/report/ mooc-stats-2019/. [Letöltve: 2020.01.05.]

Sнан, D. (2019b) EdX's 2019: Year in Review. https://www.classcentral.com/report/edx2019-year-review/. [Letöltve: 2020. 01. 05.]

Sнaн, D. (2019c) Online Degrees Slowdown: A Review of MOOC Stats and Trends in 2019: Year in Review. https://www.classcentral.com/report/moocs-stats-and-trends-2019/. [Letöltve: 2020. 01.05.] 
Sнaн, D. (2020) By the Numbers: MOOCs During the Pandemic. https://www.classcentral. com/report/mooc-stats-pandemic/. [Letöltve: 2020. 01. 05.]

Stiglitz, J. E. (1999) Knowledge as a Global Public Good. In: Global Public Goods: International Cooperation in the 21st Century. pp. 308-325.

Tong, T. \& Li, H. (2018) Demand for MOOC-An Application of Big Data. China Economic Review, Vol. 51. (Oct. 1.) pp. 194-207.

Törnqvist, L. (1936) The Bank of Finland's Consumption Price Index. Bank of Finland Monthly Bulletin, Vol. XVI. No. 10. pp. 1-34.

A cikk a Creative Commons Attribution 4.0 International License (https://creativecommons.org/licenses/ by/4.0/) feltételei szerint publikált Open Access közlemény, melynek szellemében a cikk bármilyen médiumban szabadon felhasználható, megosztható és újraközölhető, feltéve, hogy az eredeti szerző és a közlés helye, illetve a CC License linkje és az esetlegesen végrehajtott módosítások feltüntetésre kerülnek. (SID_1) 